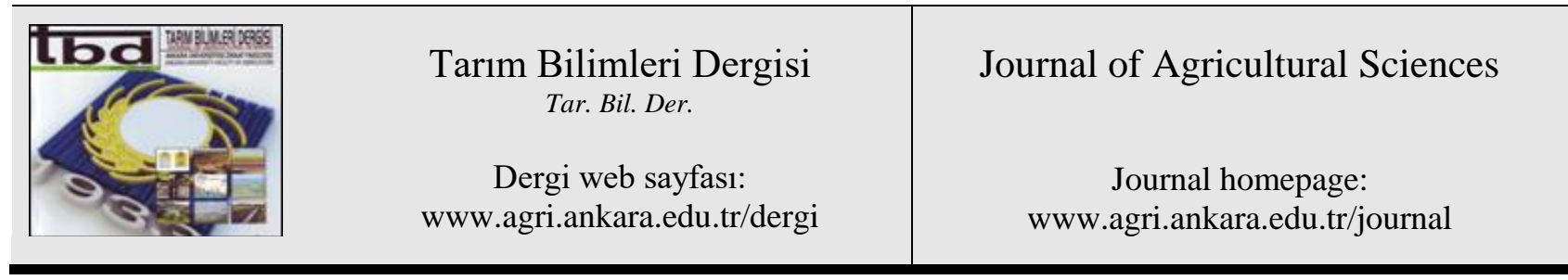

\title{
Identification of SSR Markers for Differentiating Rice (Oryza sativa L.) Varieties Marketed in Turkey
}

\author{
Necmi BEŞER ${ }^{a}$, Zeynep Çisem MUTAFÇILAR

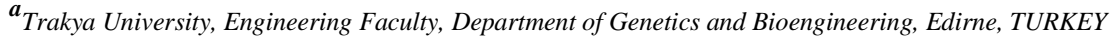

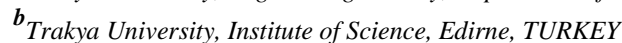

\author{
ARTICLE INFO \\ Research Article \\ Corresponding Author: Necmi BEŞER, E-mail: necmibeser@trakya.edu.tr, Tel: +90 (284) 2261217 \\ Received: 26 January 2019, Received in Revised Form: 06 April 2019, Accepted: 02 June 2019
}

AUTHORS ORCID ID:

(Necmi BEŞER: 0000-0003-1888-6316 ), (Zeynep Çisem MUTAFÇILAR: 0000-0001-8613-4883 )

\begin{abstract}
This study was carried out to identify SSR markers for the differentiation and identification of rice cultivars marketed in Turkey between 2016 and 2017. In this study 60 registered or production permitted, some local and foreign rice varieties were used as a material. DNA was isolated from single polished rice kernels for PCR amplification and rice cultivars were genotyped by 50 SSR markers. We found that 45 out of 50 SSR markers produced reproducible and polymorphic alleles. Thirty-six rice varieties had variety specific alleles among 60 rice varieties analysed in the study.
\end{abstract}

This variety specific alleles belong to only one variety and they can be used to identify rice variety among 60 rice varieties studied. Osmancık-97, Cammeo, Ronaldo and Baldo are the most import 4 varieties in Turkish rice production and milled rice market. In this study, it was found that RM152, RM144, RM259 and RM118 SSR markers can be used to differentiate and identify these most important four varieties with different combinations. Collectively, this study provided some variety specific SSR markers that can be used to differentiate and identify rice varieties sold in Turkey.

Keywords: Polished rice; Rice cultivar; SSR

\section{Introduction}

(C) Ankara Üniversitesi Ziraat Fakültesi

The quality criterias of rice vary from country to country, even from city to city within a country. However, the main quality criterias generally accepted by everyone are milling yield, physical, chemical, cooking and eating quality. Even if all quality criterias are very good, marketing mixture of different rice varieties decreases the rice quality sharply. Mixing of the rice varieties during marketing also causes unfair competition among rice industry and misleads the consumers. This is done generally by mixing low quality rice with high quality rice to sell mixed rice for higher price.

In Turkey, polished rice is generally sold under Osmanc1k-97 or Baldo varieties name. These two rice varieties are well accepted by consumers with their quality characteristics. It is very difficult to identify mixed rice kernels by checking physical characteristics of polished rice inside the package. Although the rice in the package is physically similar, the chemical and cooking properties may be different. Thus, in order to identify and differentiate polished rice kernels in the package, molecular markers need to be discovered.

Because microsatellites (SSRs) are well distributed within the genome in eukaryotic organisms, found in large numbers and show more polymorphism (Morgante \& Olivieri 1993), they are more advantageous for identification and purity analysis of vaieties than other molecular markers (Weising et al 1997; Ni et al 2002; Kostova et al 2006). It was reported that the use of SSR markers to study genetic diversity in rice also very appropriate (Powell et al 1996). 
Many SSRs have been developed for rice to use genetic diversity studies (Zhao \& Kochert 1993). It was reported that more than 20000 SSR markers were mapped for genome-specific regions in rice (Pervaiz et al 2010). Many genetic diversity and characterization studies were done by using SSRs in rice (Hossain et al 2007; Pervaiz et al 2010; Rahman et al 2012; Choudhary et al 2013; Worede et al 2013; Kumar et al 2014; Li et al 2014). Some studies on the genetic diversity of Turkish rice varieties were also done by using SSRs (Cömertpay et al 2016), RAPDs (Bay 2009) and IRAPs (Yüzbaşığlu et al 2016) markers. However, there is not a particular study to identify and differentiate rice cultivars from single polished rice kernel by using molecular markers for Turkish rice market. Thus, there is a need for the development of molecular markers to identify and differentiate rice varieties in polished rice package for a fair competition of industry and protect consumers.

The objective of this study to find out SSR markers which can be used to differentiate and identify rice varieties by using single polished rice kernel. Detected SSRs can also be used for variety identification and purity test studies in seed production.

\section{Material and Methods}

\subsection{Plant material}

In Turkey, there were 48 registered and production permitted rice cultivars at the registration list in 2016. In addition to these registered and production permitted rice varieties at registration list, some local varieties and foreign varieties were also chosen as plant material. Totally 60 rice varieties, given in Table 1, were obtained from Trakya Agricultural Research Institute and Trakya Genetics RD Consulting Production Import Export and Marketing Co Ltd. Some rice varieties used in this study are not grown anymore in Turkey, but sometimes there are polished rice with their names at the rice market. The most widely grown rice varieties in Turkey are Osmanc1k-97, Cammeo and Ronaldo. About $80 \%$ of rice growing area in Turkey was planted with these three varieties in 2017.

Table 1- List of rice varieties analysed in this study

\begin{tabular}{lllll}
\hline Akçeltik & Durağan & Kıral & Mis-2013 & Sarıçeltik \\
Altınyazı & Efe & Kırkpınar & N1-41T-1T-0T & Sürek M711 \\
Aromatik-1 & Ergene & Kızılırmak & Neğiş & Sürek-95 \\
Bafra Yıldızı & Europa & Kizıltan & Osmancık-97 & Şumnu \\
Balaban & Gala & Koral & Paşalı & Thainato \\
Baldo & Gönen & Krasnodarsky-424 & Plovdiv & Tosya Güneşi \\
Beşer & Halilbey & Küplü & Ranballi & Trakya \\
Biga İncisi & Hamzadere & Manyas Yıldızı & Ribe & Tunca \\
Cammeo & İpsala & Maratelli & Rocca & Ülfet \\
Çakmak & Kale & Meco & Rodina & Veneria \\
Demir & Karadeniz & Meriç & Ronaldo & Yatkın \\
Diyarbakır Yerli & Kargı & Mevlutbey & Sarhan & Yavuz \\
\hline
\end{tabular}

\subsection{DNA extraction from single polished rice grain}

Single polished rice kernel was used for DNA extraction. High quality gDNA was extracted from single polished rice kernel as described by Rajendrakumar et al (2007). Isolated gDNA samples were quantified spectrophotometrically by OPTIZEN NanoQ (Kaia, Panama). Quality of the gDNAs was analysed by agarose gel (0.8\%) electrophoresis. The gDNAs were diluted to $25 \mathrm{ng} \mu \mathrm{L}^{-1}$ concentration for PCR. 


\subsection{PCR amplification of SSR loci}

In this study, 50 SSR markers, which are suggested for diversity analysis in the Gramene Database (Gramene 2015) spread across all rice chromosomes, were used. The PCR amplifications of the each SSR loci were carried out in $15 \mu \mathrm{L}$ reaction mixture containing $50 \mathrm{ng}$ gDNA, $1 \mathrm{X}$ PCR buffer, $2.5 \mathrm{mM} \mathrm{MgCl} 2,0.2 \mathrm{mM}$ dNTPs, $0.5 \mu \mathrm{M}$, primers and $1 \mathrm{U}$ Taq polimerase (Invitrogen). The amplification was performed by T100 Bio-Rad thermal cycler (CA, USA) following the cycles; 2 min at $94{ }^{\circ} \mathrm{C}$ for initial denaturation, and 35 times 45 secs at $94{ }^{\circ} \mathrm{C}, 1$ min at $53-61{ }^{\circ} \mathrm{C}$ (depending on the primer $\mathrm{Tm}$ ), $1 \mathrm{~min}$ at $72{ }^{\circ} \mathrm{C}$ and $10 \mathrm{~min}$ at $72{ }^{\circ} \mathrm{C}$ for final extension.

\subsection{DNA fragment analysis}

The amplified PCR products were separated and analysed by AATI Fragment Analyser System (Advance Analytic, IA, USA). The PCR products were prepared for capillary system analysis according to the manufacturer's instructions (DNF-905 dsDNA Reagent, IA, USA). Each reaction was diluted with a 1:5 ratio by dilution buffer and $24 \mu \mathrm{L}$ of the mixture transferred to the 96 -well plate. Each well was covered by mineral oil and electrophoresis was performed by applying $9.0 \mathrm{kV}$ for $80 \mathrm{~min}$. For sizing of the SSR alleles, 1-500 bp DNA ladders were used in each run and DNA fragment sizes were calculated by system software ProSize. Results were analysed by GenAlex 6.5 software program.

\section{Results and Discussion}

Forty-five SSR markers produced reproducible and polymorphic alleles among 50 SSR markers used in this study. Five of them (RM154, RM124, RM454, RM284 and RM447) did not produce satisfactory quality PCR products, thus they were not used for the later studies. A total of 279 alleles were yielded by the 45 polymorphic SSR markers. The size of allelic DNA fragments varied from 77 bp (marker RM44) to 430 bp (marker RM171). Maximum allele numbers per locus were produced by primers RM25 with 19, and followed by RM259, RR237, RM452, RM287, RM162, RM431 and RM19 with 13, 11, 11,10, 10, 10 and 10 alleles, respectively. Average allele number was 6, 2.

\subsection{Variety specific SSR alleles for identification of rice varieties}

Identification of the variety specific alleles is one of the significant results of this study. Because variety specific alleles belong to only one variety, and they can be used for identifying desired rice variety. Variety specific alleles found in this study and their SSR locies are given in Table 2. As can be seen in Table 2, 36 rice varieties had variety specific alleles, among 60 rice varieties studied. Aromatik-1 had the highest number of variety specific allele with 17 alleles amplified by 17 SSR markers. This was followed by Akçeltik, Karadeniz and Sürek-95 with 4 variety specific alleles (Table 2).

Sixteen rice varieties had two variety specific alleles ampliphied by different SSRs. These are Rocca Kiziltan, Hamzadere, Negis, Balaban, Şumnu, Sarıçeltik, Krasnodarsky-424, Plovdiv, Sarhan, Diyarbakır yerlisi, Duragan, Meriç, Küplü, Meco and Mevlütbey (Table 2).

On the other hand, 16 varieties, İpsala, Gönen, Yatkın, Mis-2013, Veneria, Yavuz, Biga İncisi, Kral, Karg1, N1-41TIT-OT, Tahinato, Bafrayıldızı, Kızılırmak and Baldo had only one variety specific allele (Table 2). In this group Baldo, Gönen and Yatkın are important rice varieties in polished rice market in Turkey.

One of the significant result of this study is to find out variety specific alleles for 36 rice varieties including Baldo. Because Baldo is marketed with the highest price in Turkish rice market, polished kernel of some other rice varieties can sometimes be mixed with polished kernel of Baldo variety, and sold as a Baldo variety with higher price. Moreover, some rice varieties with the similar physical characteristics of Baldo polished rice kernel are marketed as a Baldo rice. Baldo specific 150 bp allele amplified by RM118 marker can be used to identify Baldo polished rice kernels among 60 rice cultivars studied. Gönen variety has similar physical characteristics of Baldo polished rice, and these two varieties can be also differentiated by variety specific alleles of Baldo and Gönen. Yatkın variety is one of the newest variety and its planting area is increasing every year. Cultivar specific 138bp allele amplified by RM408 can be used to distinguish Yatkın rice variety from other 60 varieties.

Pal et al (2004) reported that the same allel (147 bp) was amplified by RM255 in traditional Basmati rice varieties, which was different to that in IR 36 (145 bp) and Azucana. They suggested to use RM255 marker to differentiate traditional Basmati and non Basmati rice varieties. 
Table 2- Variety specific allels

\begin{tabular}{|c|c|c|c|c|c|}
\hline Variety & Locus & Allele & Variety & Locus & Allele \\
\hline Rocca & RM25 & 186 & Aromatik-1 & RM507 & 255 \\
\hline Rocca & RM431 & 256 & Aromatik-1 & RM271 & 98 \\
\hline K1z1ltan & RM510 & 124 & Aromatik-1 & RM307 & 131 \\
\hline K1z1ltan & RM431 & 259 & Aromatik-1 & RM474 & 233 \\
\hline Sürek-95 & RM277 & 124 & Aromatik-1 & RM484 & 300 \\
\hline Sürek-95 & RM118 & 181 & Aromatik-1 & RM118 & 163 \\
\hline Sürek-95 & RM452 & 174 & Aromatik-1 & RM178 & 116 \\
\hline Sürek-95 & RM452 & 209 & Aromatik-1 & RM287 & 121 \\
\hline Hamzadere & RM507 & 267 & Aromatik-1 & RM162 & 219 \\
\hline Hamzadere & RM413 & 86 & Aromatik-1 & RM452 & 211 \\
\hline İpsala & $\mathrm{RM} 25$ & 148 & Aromatik-1 & RM161 & 165 \\
\hline Negis & RM5 & 113 & Veneria & RM431 & 224 \\
\hline Negis & RM452 & 192 & Mis-2013 & RM408 & 354 \\
\hline Gönen & RM431 & 254 & Yavuz & RM19 & 221 \\
\hline Demir & RM259 & 175 & D.bakır yerlisi & RM25 & 163 \\
\hline Ulfet & RM452 & 216 & D.bakır yerlisi & RM413 & 92 \\
\hline Balaban & RM171 & 422 & Duragan & RM552 & 181 \\
\hline Balaban & RM44 & 97 & Duragan & RM55 & 233 \\
\hline Sumnu & RM536 & 246 & Biga incisi & RM237 & 135 \\
\hline Sumnu & RM338 & 189 & Kral & RM133 & 232 \\
\hline Yatkın & RM408 & 138 & Meric & RM19 & 224 \\
\hline Sarıceltik & RM259 & 199 & Meric & RM552 & 231 \\
\hline Sarıceltik & RM452 & 201 & Kuplu & RM178 & 118 \\
\hline Krasnodorsky & RM215 & 164 & Kuplu & RM452 & 342 \\
\hline Krasnodorsky & RM162 & 256 & Karg1 & RM455 & 129 \\
\hline Akceltik & RM237 & 374 & Baldo & RM118 & 150 \\
\hline Akceltik & RM484 & 295 & N1-4IT-IT-OT & RM55 & 231 \\
\hline Akceltik & RM259 & 195 & Meco & RM105 & 132 \\
\hline Akceltik & RM162 & 250 & Meco & RM144 & 248 \\
\hline Plovdiv & RM25 & 165 & Mevlutbey & RM162 & 240 \\
\hline Plovdiv & RM259 & 197 & Mevlutbey & RM431 & 252 \\
\hline Sarhan & OSR13 & 103 & Thainato & RM178 & 132 \\
\hline Sarhan & RM338 & 270 & Bafrayıldızı & RM514 & 254 \\
\hline Aromatik-1 & RM19 & 247 & Kiz1lirmak & RM316 & 214 \\
\hline Aromatik-1 & RM536 & 232 & Karadeniz & RM237 & 375 \\
\hline Aromatik-1 & RM489 & 240 & Karadeniz & RM474 & 268 \\
\hline Aromatik-1 & RM11 & 152 & Karadeniz & RM178 & 112 \\
\hline Aromatik-1 & RM283 & 156 & Karadeniz & RM125 & 225 \\
\hline Aromatik-1 & RM1 & 116 & & & \\
\hline
\end{tabular}

\subsection{Differentiating and Identification of rice varieties with using several alleles}

Osmanc1k-97, Cammeo and Ronaldo rice varieties account for about 80 percent of the total planted area of rice in Turkey. Thus it is important to identify and differentiate these three varieties as well as Baldo rice variety from other rice varieties sold in Turkish rice market using molecular markers. Interestingly, any variety specific allele was not found for those 4 rice varieties except Baldo. On the other hand, in order to differentiate these three varieties from each other and Baldo variety, 3 SSR markers (RM152, RM144, RM259) and Baldo specific RM118 (150 bp) allele were identified. Electropherogram results of AATI analyser for RM152, RM144, RM259 SSR markers to differentiate and identify Baldo, Osmancik-97, Ronaldo and Cammeo varieties were given in Figure 1, 2 and 3. As can be seen in Figure 1, 2 and 3, Baldo, Ronaldo, Cammeo and Osmancik-97 varieties can be differentiated each others with their alleles amplified by these 3 SSRs (RM152, RM144, RM259). RM152 amplified 143 bp allele, 146 bp, 152 bp and 152 bp alleles from Baldo, Ronaldo, Osmancik-97 and Cammeo respectively. With the use of RM152 allele, Baldo and Ronaldo varieties can be differentiated from Cammeo, Osmanc1k-97 and each other. However, it was not possible to differentiate Osmanc1k-97 and Cammeo with RM152 (Figure 1). On the other hand, RM144 amplified 266 bp allele for Osmancik-97, while it amplified 254 bp, 255 bp and 255 bp alleles for Ronaldo, Baldo and Cammeo respectively. RM144 marker can be used to differentiate Osmancik-97 from Ronaldo, Cammeo and Baldo (Figure 2). In addition, while RM259 amplified 172 bp allele for Baldo and Cammeo, it amplified 175 bp and 178 bp alleles for Osmancık-97 and Ronaldo respectively (Figure 3), indicating that RM259 marker can be used to differentiate Baldo and Cammeo 
from Osmanc1k-97 and Ronaldo. This marker can also be used to differentiate Osamancik-97 and Ronaldo from each other. With the use of only these three SSR markers (RM152, RM144 and RM259), the differentiation and identification of Baldo, Osmanc1k-97, Ronaldo and Cammeo varieties, which have more than $80 \%$ market share in Turkish rice market, can be done. In addition to these three markers, Baldo specific $150 \mathrm{bp}$ allele amplified by RM188 can also be used together with these three markers (RM152, RM144 and RM259) to differentiate and identify these four markets dominating varieties.

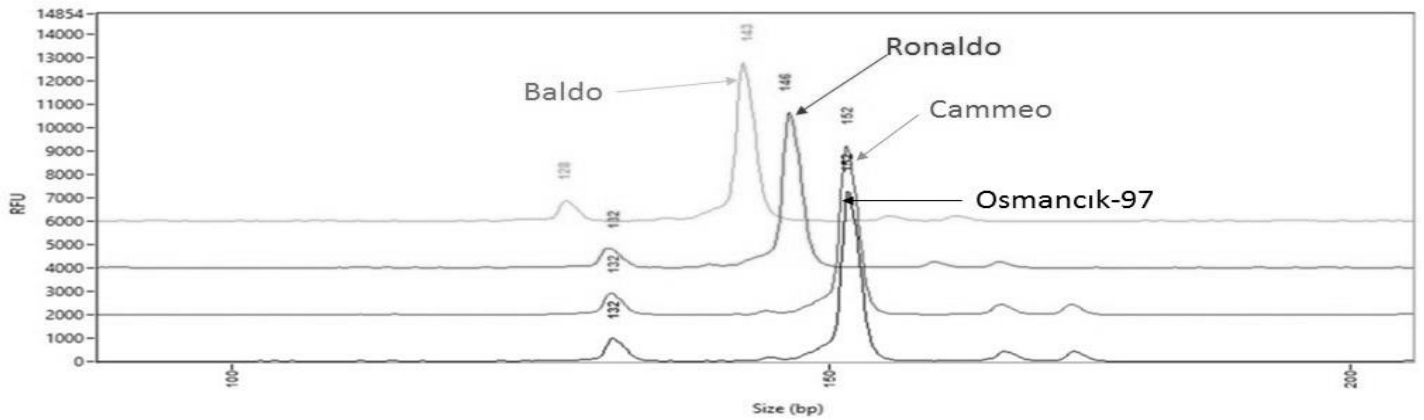

Figure 1- Electropherogram of Baldo, Ronaldo, Cammeo and Osmancık-97 rice varieties for RM152 marker

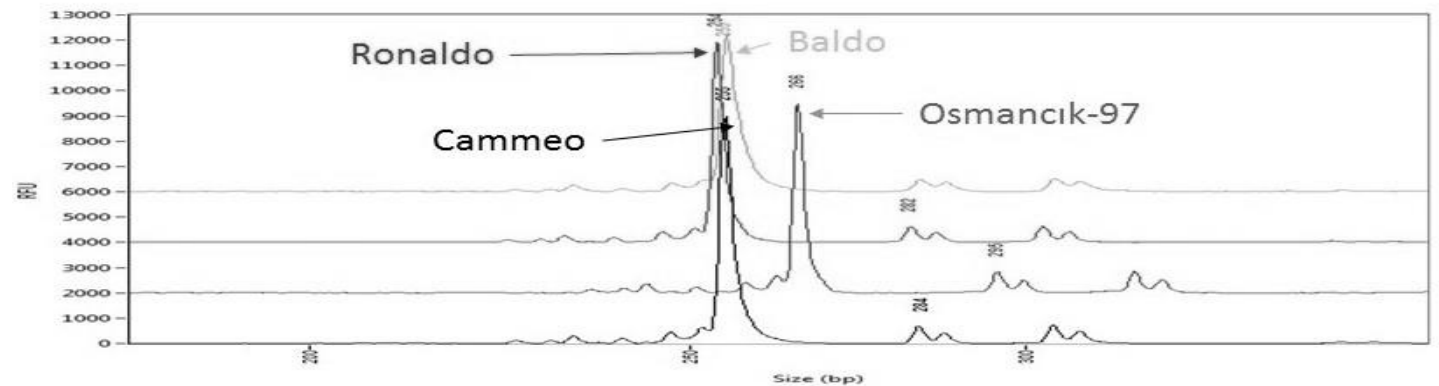

Figure 2- Electropherogram of Baldo, Ronaldo, Osmancık-97 and Cammeo rice varieties for RM144 marker

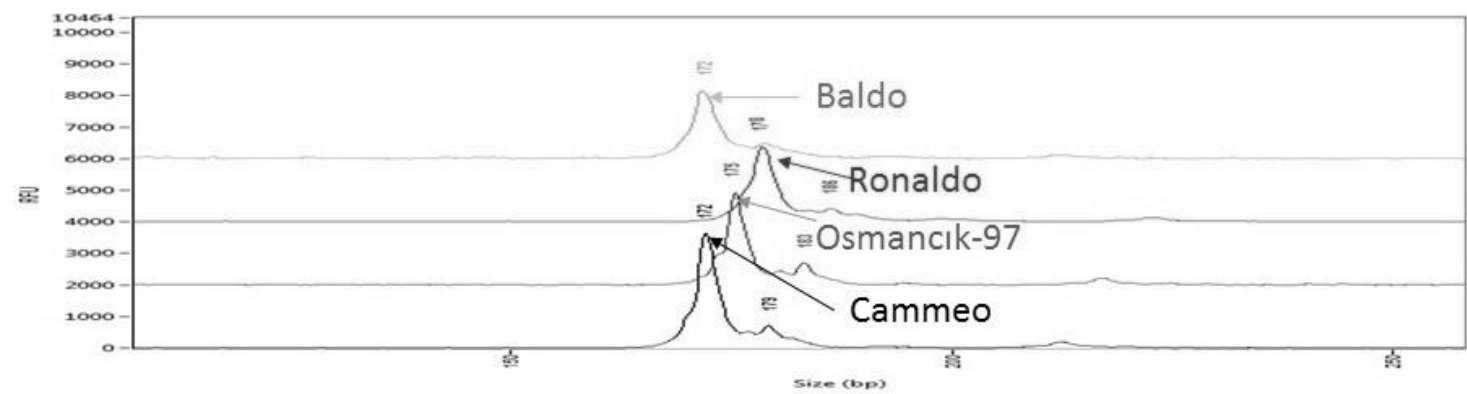

Figure 3- Electropherogram of Baldo, Ronaldo, Osmancık-97 and Cammeo rice varieties for RM259 marker

\section{Conclusions}

This study was carried out to differentiate and identify rice varieties by means of SSRs analysis with using single polished rice kernel in Turkey. It was found that 36 rice varieties can be differentiated and identified with variety specific alleles, while rest of the varieties can be differentiated and identified using several allele combinations. The most imported rice varieties for Turkish rice market, namely Osmancık-97, Cammeo, Ronaldo and Baldo varieties. These four varieties can be differentiated from each other using RM152, RM144, RM259 and RM188 SSR markers.

\section{Acknowledgements}

This study was supported by General Directorate of Agricultural Research and Policies, Ministry of Food, Agriculture and Livestock of Turkey (Project Number TAGEM/AR-GE/58). The authors gratefully acknowledge General Directorate of Agricultural Research and Policies, Ministry of Food, Agriculture and Livestock of Turkey for supporting this study. 


\section{References}

Bay S (2009). Türk çeltik çeşitlerinin (oryza satıva 1.) tohum depo proteinleri ve Random amplified polymorphic DNA (RAPD) belirleyicileri ile genetik analizi. Diss. Yüksek Lisans Tezi, Kahramanmaraş Sütçü İmam Üniversitesi, Fen Bilimleri Enstitüsü, Biyoloji Ana Bilim Dal, Kahramanmaraş

Choudhary G, Ranjitkumar N, Surapaneni M, Deborah D A, Vipparla A, Anuradha G, Siddiq E A \& Vemireddy L R (2013). Molecular genetic diversity of major indian rice cultivars over decadal periods. Plos One. 8(6): e66197

Cömertpay G, Baloch F S, Derya M, Andeden E E, Alsdeh A, Sürek H \& Özkan H (2016). Population structure of rice varieties used in Turkish rice breeding programs determined using simple-sequence repeat and inter binding site-retrotransposon data. Genetics and Moleculer Research. 15 (1): gmr.15017158

Gramene (2015). Panel of 50 standard SSR markers. Retrieved in December, 20, 2015 from http://archive.gramene. org/db/markers/ssrtool

Hossain Z, Rasul M G, Ali M S, Iftekharuddaula K M \& Mian M A K (2007). Molecular characterization and genetic diversity in fine grain and aromatic landraces of rice using microsatellite markers. Bangaldes Jornal of Plant Breeding and Genetics 20(2): 110

Kostova A, Todorovska E, Christov N, Hristov K \& Atanassov A (2006). Assesment of genetic variability induced by chemical mutagenesis in elite maize germplasm via SSR markers. Journal of Crop Improvement 16: 37-48

Kumar S, Tantwai K, Kottapalli P R \& Katiyar S K (2014). Genetic diversity analysis of rice genotypes collected from different villages of Chhattisgarh using simple sequence repeat (SSR) markers. Advances in Plant Sciences 25(2): 419-422

Li F P, Lee S, Kwon S W, Li G \& Park Y J (2014). Analysis of genetic diversity and trait correlations among Korean landrace rice (Oryza sativa L.). Genetics and Molekuler Research 13(3): 6316-6331

Morgante M \& Olivieri A (1993). PCR-amplified microsatelites as markers in plant genetics. Plant Journal 3: 175-182

Ni J, Colowit P M \& Mackill D J (2002). Evaluation of genetic diversity in rice subspecies using microsatellite markers. Crop Science 42: 601-607

Pal S, Jain S, Saini N, Jain A, Jain R K \& Jain A (2004). Identification of microsatellite markers for differentiating some Basmati and non-Basmati rice varieties. Indian Journal of Biotechnology 3: 519-526

Pervaiz Z H, Rabbani M A, Khaliq, Pearce S R \& Malik S A (2010). Genetic diversity associated with agronomic traits using microsatellite markers in Pakistani rice landraces. Electronic Journal of Biotechnology 13(3): 7-9

Powell W, Machray G C \& Provan J (1996). Polymorphism revealed by simple sequence repeats. Trends Plant Science 1: 215-222

Rahman M M, Rasaul M G, Hossain M A, Iftekharuddaula K M \& Hasegawa H (2012). Moleculer characterization and genetic diversity analysis of rice (Oryza sativa L.) using SSR markers. Journal of Crop Improvment 26: 244-257

Rajendrakumar P, Sujatha K, Rao K S, Kumar P N, Viraktamath B C, Balachandran S M \& Sundaram R M (2007). A protocol for isolation of DNA suitable for rapid seed and grain purity assessments in rice. Rice Genentics Newsletter 23: 92-94

Yüzbaşığlu G, Yılmaz S \& Gözükırmızı N (2016). Houba retrotransposon-based molecular markers: a tool for variation analysis in rice. Turkish Jornual of Agriculture and Forestry 40: 456-464

Weising K, Winter P, Hüttel B \& Kahl G (1997). Microsatellite markers for moleculer breeding. Journal of Crop Production 1: 113143

Worede F, Sreewongchai T, Phumichai C \& Sripichitt P (2013). Genetic diversity analysis of rice cultivars from various origins using simple sequence repeat (SSR) markers. African Journal of Biotechnology 12(26): 4074-4081

Zhao X \& Kochert G (1993). Phylogenetic distribution and genetic mapping of a (GGC)n microsatellites from rice (Oryza sativa L). Plant Moleculer Biology 21: 697-614 